TITLE:

\title{
Preservation of skin free-flap using trehalose.(Abstract_要旨)
}

$\operatorname{AUTHOR}(\mathrm{S})$ :

Kitahara, Kiyoshi Ameriko

CITATION:

Kitahara, Kiyoshi Ameriko. Preservation of skin free-flap using trehalose. 京都大学, 1998, 博士(医学)

ISSUE DATE:

1998-07-23

URL:

http://hdl.handle.net/2433/182252

RIGHT: 


\section{【177 】}

氏 名菲原韻䒫志 アメリコ

学位 (専攻分野) 博士 (医 学)

学位記番号医 博第 2047 号.

学位授与の日付 平成 10 年 7 月 23 日

学位授与の要件 学位 規則第 4 条第 1 項 該 当

研究科. 専攻医学研究科外科系専攻

学位論文題目 Preservation of skin free-flap using trehalose.

（トレハロースを用いた遊離皮弁の保存について）

(主查)

論文調查委員教 授山岡義生教授田中紘一教授西村善彦

\section{論文内容 の要旨}

くはじめに>

事故等により切断された組織を再接着することが可能な施設はまだ少なく, 患者を手術可能なセンターに搬送しなければ ならないことが多い。従って，切断組織を長時間保存することができる方法の開発が必要となる。

1969年にCollinsらの作製した腎臟保存液はその後改良が加えられ，Euro-Collins（EC）液として一般的な臓器の保存に 広く使用され，その有効性はすでに証明されている。

そこで本研究では，Euro-Collins（EC）液中のグルコースを細胞膜保護作用を持つ二糖類であるトレハロースに置換し た保存液を作製し，それの皮弁保存効果を検討した。

$<$ 方法 $>$

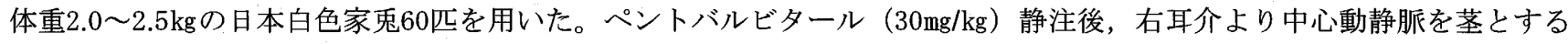
直径 $6 \mathrm{~cm}$ の遊離皮弁を軟骨膜下で挙上し摘出した。このとき，神経，血管の剥離採取は顕微鏡下で行った。この遊離皮弁を

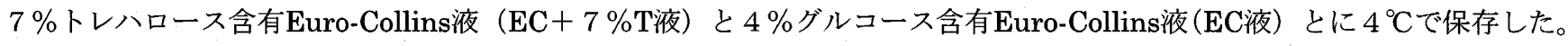
保存開始24（n=10）４8（n=10），72（n=10）時間後に，これらの遊離皮弁を同一家免の反対側の耳介中心動静脈に顕微 鏡下に10-0ナイロン系で血管吻合を行って移植した。吻合部の開存を確認後, 皮弁は 5 - 0ナイロン糸で固定した。なお, すべての微小血管吻合は同一術者が行なった。

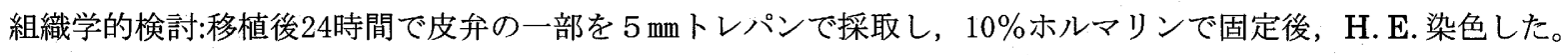

生着率の評価:移植1週間後，皮弁の生死を判定し，その生着率を比較した。

統計処理 : 各々の生存率の比較はFisher's exact testで行ない， $\mathrm{P}<0.05$ 有意差ありとした。

$<$ 結果 $>$

生着した皮弁の組織学的検討 : EC液に72時間保存した群では, 毛細血管の破壊, 真皮膠原線維の完全な破壞, 炎症細胞 の浸潤, 脂肪組織の変性が認められた。しかし，EC+ 7 \% T液群では 72 時間保存でも，皮膚及び皮下組織はほぼ正常であっ た。

生着率の評僻：移植後 7 日目の生着率は，24時間保存では両溶液共に $100 \%$ であった。また，EC液 48 時間保存では60\% に対しEC+ 7 \%T液では $90 \%$ でった。さらに，EC液 72 時間保存では $20 \%, \mathrm{EC}+7 \% \mathrm{~T}$ 夜では $70 \%$ と著明な有意差を認め た $(\mathrm{P}<0.05)$ 。 
<考察 $>$

トレハロースは酵母, 海草, きのこ, 昆虫等に含まれる非還元二糖類で, 細胞膜のリン脂質と反応してリン脂質二重構造 を保護する作用があると報告されている。本研究では含有する糖のみをグルコースからトレハロースに変えた以外は, まっ たく同じ成分の二種類の液による遊離皮弁の保存効果を比較し検討した。その結果，トレハロースを用いた保存液では，阻 血再灌流障害が最も顕著にあらわれる移植早期の組織に変性，破壞が少なく，最終的な生着率も高かった。以上，本研究に より遊離皮弁の保存に対するトレハロース含有保存液の有効性が示された。

\section{論 文 審 查の 結 果 の 要 旨}

マイクロサージャリーの進歩により切断指の再接着が可能となったが, 虚血が長時間続くと組織の機能回復は不可能とな る。この時間的制限を延長させる目的で，皮弁保存に対するトレハロース含有Euro-Collins液の有用性を検討した。実験に は日本白色家鬼60匹を用いた。耳介中心動静脈を茎として耳介皮弁を起し, 完全切断後, トレハロース含有Euro-Collins液 (T群）とEuro-Collins夜（G群）に24〜72時間保存した後，再び同一家鬼の対側耳介中心動静脈に吻合移植した。再灌流24 時間後のHE染色による組織学的観察，加えて，1 週間後の皮弁の生死を観察評価した。生着率は48時間保存でT群 $90 \%$ に 対しG群 $60 \%$ ，72時間保存でT群70\%に対しG群 $20 \%$ と良好で，組織学的にもT群の優位性が裹づけられた。特に 72 時間保存 では統計学的有意に T群の生着率が優れていた。

以上の研究は遊傩皮弁の保存時間延長に貢献し，切断指再接着術に奇与するところが多い。

従って，本論文は博士（医学）の学位論文として価値あるものと認める。

なお，本学位授与申請者は，平成10年 6 月 22 日実施の論文内容とそれに関連した試問を受け，合格と認められたものであ る。 